\title{
WHEAT GROWTH AND NUTRIENT UPTAKE AFTER PHOSPHORUS AND POTASSIUM APPLICATIONS IN SALINE-SODIC FIELD OF SEMI-ARID REGION
}

\author{
CRESCIMENTO DO TRIGO E ABSORÇÃO DE NUTRIENTES APÓS APLICAÇÕES \\ DE FÓSFORO E POTÁSSIO EM CAMPO SALINO-SÓDICO DO SEMI-ÁRIDO
}

\author{
Zahid HUSSAIN ${ }^{1}$; Riaz Ahmad KHATTAK ${ }^{2}$; Ping AN ${ }^{3}$; Yang SHAO ${ }^{3}$; Muhammad IRSHAD*4 \\ 1. Department of Development Studies, COMSATS University Islamabad, Abbottabad Campus, Pakistan \\ 2. The Brains Institute, Peshawar, Pakistan; 3. Arid Land Research Center, Tottori University, Hamasaka, Tottori, Japan; 4. Department \\ of Environmental Sciences, COMSATS University Islamabad, Abbottabad Campus, Pakistan *Corresponding author: \\ mirshad@cuiatd.edu.pk
}

\begin{abstract}
Nutrient deficiency is a limiting factor in saline-sodic soils resulting in low crop production. The study investigated wheat response to $\mathrm{P}$ and $\mathrm{K}$ added to soils. The $\mathrm{K}$ was applied at 0 (K0), 75 (K1), $150(\mathrm{~K} 2) \mathrm{kg} \mathrm{K}_{2} \mathrm{O} \mathrm{ha}^{-1}$ as $\mathrm{K}_{2} \mathrm{SO}_{4}$ and at (0 (P0), $60(\mathrm{P} 1), 120(\mathrm{P} 2) \mathrm{kg} \mathrm{P}_{2} \mathrm{O}_{5} \mathrm{ha}^{-1}$ as $\left(\mathrm{NH}_{4}\right)_{2} \mathrm{HPO}_{4}$ in three replications under two-factorial randomized complete block (RCB) design. Both treatments significantly enhanced wheat grain $(118 \%)$ and dry matter yield $(60 \%)$ at $\mathrm{P} 2 \mathrm{~K} 2$ compared to control. The $\mathrm{P}$ treatments significantly affected leaf $\mathrm{P}, \mathrm{Mg}, \mathrm{SO}_{4}, \mathrm{Ca}: \mathrm{P}, \mathrm{SO}_{4}: \mathrm{P}$ ratios and soil $\mathrm{P}, \mathrm{Ca}: \mathrm{P}, \mathrm{Cl}: \mathrm{P}$ and $\mathrm{SO}_{4}: \mathrm{P}$ ratios, while $\mathrm{K}$ on leaf $\mathrm{K}, \mathrm{Na}, \mathrm{Ca}, \mathrm{SO}_{4}$ concentration, $\mathrm{K}: \mathrm{Na}, \mathrm{K}: \mathrm{Ca}, \mathrm{SO}_{4}: \mathrm{P}, \mathrm{Ca}: \mathrm{P}$ ratios and soil $\mathrm{pH}, \mathrm{Na}, \mathrm{K}, \mathrm{Ca}, \mathrm{SO}_{4}$ concentrations, SAR, Na:K, Ca:K and Na:Ca ratios. Leaf $\mathrm{Na}$ was decreased to $85.3 \mathrm{mmol}(+) \mathrm{kg}^{-1}$ at $\mathrm{K} 2$ compared to 105.3 mmol ( $+\mathrm{kg}^{-1}$ at $\mathrm{P} 2 \mathrm{~K} 0$. Negative correlation $\left(\mathrm{R}^{2}=0.906\right)$ of leaf $\mathrm{K}: \mathrm{Na}$ was found with leaf $\mathrm{Na}$ concentration. The correlation of dry matter was higher $\left(\mathrm{R}^{2}=0.851\right)$ with leaf $\mathrm{K}: \mathrm{Na}$ ratio than grain yield $\left(\mathrm{R}^{2}=0.392\right)$. It is concluded that the addition of $\mathrm{K}$ and $\mathrm{P}$ addition shows beneficial effects in improving crop nutrition and wheat yield in the saline-sodic soil environment.
\end{abstract}

KEYWORDS: Arid region. P. K. Saline-sodic soil. Semi-arid region. Wheat growth.

\section{INTRODUCTION}

Reclamation of salt-affected soils through appropriate on-farm fertility management practices serves as a vital tool for the enhancement of crop production (JORDAN et al., 2004). Under salt stress, proper fertilizer applications to the soil can increase crop yields (HUSSAIN et al., 2014). Potassium (K) and phosphorus (P) can be important in minimizing the negative impacts of high salt stress in soils (GARG; GUPTA, 1998). The plants' tolerance against salt stress may be improved by optimized $\mathrm{K}$ nutrition (RÖMHELD; KIRKBY, 2010) as K plays important role in regulating the osmotic potential of crops and minimizing salt stress in saline environments. However, the $\mathrm{P}$ and salinity interactions in plant nutrition are complicated and vary with crop species, types of salts, levels of salinity, growth conditions, and the $\mathrm{P}$ concentrations of growing media (NISTE et al., 2014).

Salinity compromises the agricultural potential as well as imparts serious implications on the socio-economic conditions of the farming community (HAIDER; HOSSAIN, 2013). There is an agreement that higher concentrations of salts in the rhizosphere create the osmotic stress which disturbs the nutrient balance and develops specific ion toxicity in salt-affected soils.

A positive relationship between $\mathrm{K}$ uptake and the salinity tolerance in wheat and barley was reported (CUIN et al., 2008). The accumulation of compatible solutes by plant tissues is improved in the presence of $\mathrm{K}$ which helps to mitigate salinity induced damages. For example, the presence of proline minimizes the effects of high osmotic pressure by salts in soil and water and permits water uptake by plants, protects enzymes and proteins, and improves the cell wall structure (SUN et al., 2015). The application of $\mathrm{K}$ in the presence of $\mathrm{Ca}$ reversed the salinity induced stress in Cichorium endivia L., cv. Green Curled (TZORTZAKIS, 2010). The adverse effects of salinity on plants grown on $\mathrm{P}$ deficient soils and improved wheat growth in moderate and high soil salinity with $\mathrm{P}$ are reported. Also, $\mathrm{P}$ improved uptake of $\mathrm{N}, \mathrm{P}, \mathrm{K}$, and $\mathrm{Zn}$ in sandy and calcareous soils (WAGDI et al., 2013). The physiology of the wheat plants was stabilized with $\mathrm{P}$ application which was due to supporting $\mathrm{K}$ transport in the plant (KHAN et al., 2013). Studying the interactive effects of $\mathrm{K}$ and $\mathrm{P}$ nutrition on wheat under natural field conditions of salinity is vital to understand the crop response and nutrient uptake. 
The impacts of $\mathrm{P}$ and $\mathrm{K}$ fertilizers on soil reclamation and growth of maize and sugar beet were studied in the same area (HUSSAIN et al., $2014 ; 2015)$. The present study aimed to further investigate the interactions of $\mathrm{P}$ and $\mathrm{K}$ and salinity on wheat growth and nutrient uptake in a salinesodic environment.

\section{MATERIALS AND METHODS}

\section{Background and description of the study location}

Pakistan falls in arid and semi-arid climate region with salt-affected soils ranging from $5.73 \mathrm{~m}$ ha (RASHID, 2006) to $6.67 \mathrm{~m}$ ha (ALI et al., 2004). This poses a major threat to the sustainability of agriculture in Pakistan. District Kohat lies in southern Khyber Pakhtunkhwa province of Pakistan with a large area affected by salinity and sodicity (HUSSAIN et al., 2015). High evapotranspiration and low rainfall elevate salt accumulation in the soil profile. The use of saline groundwater for irrigation because of the unavailability of freshwater, low rainfall, and high salinity stress have aggravated the situation to the extent that most farmers have abandoned farming as their major livelihood resources.

The experimental field lies in Tehsil Lachi of District Kohat in the north-western province of Pakistan. The soils are mixed hyperthermic Typic Halusteps (Soil Survey of Pakistan, 2007). The region is semi-arid to sub-humid subtropical continental situated in longitude $32^{\circ} 47^{\prime}$ and $34^{\circ} 5^{\prime}$ North and latitude $69^{\circ} 53^{\prime}$ and $72^{\circ} 1^{\prime}$ 'East (Soil Survey of Pakistan, 2007). Soil is calcareous, yellowish to reddish-brown with fine sandy loam to silty clay and clay loam textured and is poorly structured. Groundwater used for irrigation is of poor quality with an $\mathrm{EC}_{\mathrm{iw}}$ level of $2.2-3.0 \mathrm{dS} \mathrm{m}^{-1}$. The soils of the area are classified as saline-sodic soils based on measured parameters $\left(\mathrm{EC}_{\mathrm{e}}=5.0-9.0\right.$ $\left.\mathrm{dS} \mathrm{m} \mathrm{m}^{-1}, \mathrm{SAR}>15\right)$.

\section{Experimentation}

A farmer's field with characteristics of salinity and sodicity was selected for the experiment. The $\mathrm{K}_{2} \mathrm{SO}_{4}$ was applied at three doses of 0,75 , and $150 \mathrm{~kg} \mathrm{~K}_{2} \mathrm{O} \mathrm{ha}^{-1}$ while di-ammonium phosphate (DAP) at three doses of 0,60 , and $120 \mathrm{~kg}$ $\mathrm{P}_{2} \mathrm{O}_{5} \mathrm{ha}^{-1}$ in 27 plots of $5 \times 5 \mathrm{~m}^{2}$ in three replications. The urea was applied as a basal dose to all the plots uniformly at $120 \mathrm{~kg} \mathrm{~N} \mathrm{ha}^{-1}$. Inqilab-91 was selected as the experimental wheat variety which is widely used as a major wheat crop in the study area, while seed rate was kept as $120 \mathrm{~kg} \mathrm{ha}^{-1}$. Two-factorial randomized complete block (RCB) design was applied to the experiment. The experiment was completed at crop maturity.

\section{Analytical procedures}

Before the sowing of the crop and the start of irrigation, composite soil samples, and groundwater samples were collected and analyzed. The plastic bottles were cleaned and rinsed for the collection of groundwater samples. The samples were filtered using Whatman filter paper No. 40 and saved for further analysis. At crop maturity, grain, and dry matter yield $\left(\mathrm{Mg} \mathrm{ha} \mathrm{h}^{-1}\right)$ of wheat were determined. Fully matured and young leaves of wheat plants were collected prior to harvesting of the crop. The leaf samples were cleaned with purified water and dehydrated in an oven at $70{ }^{\circ} \mathrm{C}$ for 2 days. After drying, the leaves were milled and saved for further analyses. The leaf samples were wet-digested as follows: A $0.5 \mathrm{~g}$ of oven-dried leaf samples were weighed and transferred to flask. A 10 $\mathrm{mL}$ of concentrated $\mathrm{HNO}_{3}$ was added to the samples and were left overnight. The next day, $4 \mathrm{~mL}$ of $\mathrm{HCIO}_{4}$ was added to the flask and gently heated in block heater for complete digestion. The digested material was cooled and filtered. Distilled water was added to make the desired volume. Chemical analysis for cations and anions in leaf samples was done.

Soil samples from each pot were collected at the depth of $0-30 \mathrm{~cm}$ after harvesting of crops. Samples were openly dried and then crushed and sieved through $2 \mathrm{~mm}$ sieve. The samples were then saved for further analyses. The texture of the soils was determined using the hydrometric method. A $250 \mathrm{~g}$ soil was weighed, and the distilled water was added carefully to make the saturated soil paste while continuously stirring with a spatula. After that, the shining paste was developed, it was kept for a night to completely dissolve the salts, as well as the equilibrium, was achieved (RICHARDS, 1954). The samples were extracted to obtain clear extract using an aspirator. The saturation extract was refrigerated.

The electrical conductivity (EC) of the saturation extracts and the groundwater samples was measured with digital Electrical conductivity meter, Wiss. Techn. Werkstatten (WTW) D12 Weilheim. The $\mathrm{pH}$ of groundwater samples as well as suspension of 1:5 soil: water was determined with 105 Ion analyzer $\mathrm{pH}$ meter (MCLEAN, 1982; THOMAS, 1996). The $\mathrm{Na}$ and $\mathrm{K}$ concentrations in mmol $(+) \mathrm{L}^{-1}$ were determined in soil saturated extracts, groundwater, and plant samples using the Perkin-Elmer flame photometer model No. 2380. The $[\mathrm{Ca}]$ and $[\mathrm{Mg}]$ in saturation extract was 
Wheat growth...

determined by titration methods (Richards, 1954). The SAR of saturation extract and the groundwaters was calculated using mmol $(+) \mathrm{L}^{-1}$ concentrations of $\mathrm{Na}, \mathrm{Ca}$, and $\mathrm{Mg}$ by the following formula.

$$
S A R=\frac{[\mathrm{Na}]}{\sqrt{\frac{[\mathrm{Ca}+\mathrm{Mg}]}{2}}}
$$

MSTATC statistical program was used for statistical analysis of the data. Regression analysis was performed for important variables such as yields of wheat and concentrations of ions and their ratios to understand important relationships.

\section{RESULTS}

\section{Wheat yield}

There was a significant effect of $\mathrm{K}$ and $\mathrm{P}$ treatments on grain $(\mathrm{P}<0.01$ and $\mathrm{P}<0.001)$ and dry matter $(\mathrm{P}<0.001)$ yields of wheat. Grain yield was significantly $\quad(\mathrm{P}<0.05) \quad$ influenced by $\mathrm{P}-\mathrm{K}$ interactions but non-significant for dry matter yield (Table 1). Grain yield enhanced by 28 and 4.0 at $\mathrm{P} 1 \mathrm{~K} 1$ and $\mathrm{P} 1 \mathrm{~K} 2$ and $40 \%$ and $16 \%$ at $\mathrm{P} 2 \mathrm{~K} 1$ and $\mathrm{P} 2 \mathrm{~K} 2$, respectively, comparative toK 1 and $\mathrm{K} 2$ at $\mathrm{P} 0$. The increase on the other hand was by 50 and $88 \%$ at $\mathrm{K} 1$ and $\mathrm{K} 2$ without $\mathrm{P}$ but elevated to 93 and $95 \%$ at $\mathrm{P} 1$ and to 110 and $118 \%$ at $\mathrm{P} 2 \mathrm{ha}^{-1}$, respectively, when compared with P0K0 (Table 1). There seemed to be a progressive increase in yield at all $\mathrm{K}$ levels at P0. But with P1 and P2 addition at these $\mathrm{K}$ levels demonstrated a much higher effect of $\mathrm{P}$ on wheat grain yield.
HUSSAIN, Z. et al.

The significant $(\mathrm{P}<0.001)$ increase in dry matter (DM) yield was observed with $\mathrm{P}$ and $\mathrm{K}$ treatments. The DM yield improved by 7 and $23 \%$ at $\mathrm{K} 1$ and $\mathrm{K} 2$ with $\mathrm{P} 0,18$ and $26 \%$ at $\mathrm{P} 1$ and 28 and $61 \%$ at P2, respectively, compared to P0K0 (Table 1). The dry matter yield was highest at $\mathrm{P} 2 \mathrm{~K} 2$ as compared to $\mathrm{P} 0 \mathrm{~K} 0$. The increasing rates of $\mathrm{K}_{2} \mathrm{O}$ and $\mathrm{P}_{2} \mathrm{O}_{5}$ in saline-sodic soils consistently enhanced dry matter yield as shown by mean $(n=9)$ data in Table 1. The analysis of variance (ANOVA) shows the influence of $\mathrm{P}, \mathrm{K}$ treatments on yields of wheat grown under salt-affected conditions. The $\mathrm{P}$ treatments improved grain yields while $\mathrm{K}$ promoted dry matter yield under salt-affected conditions.

\section{Chemical analysis of wheat leaf samples}

The ANOVA for chemical analysis of leaf tissues of wheat showed that the application of $\mathrm{P}$ significantly influenced leaf concentrations of $\mathrm{P}$ $(\mathrm{P}<0.001), \mathrm{Mg}(\mathrm{P}<0.01), \mathrm{SO}_{4}(\mathrm{P}<0.001)$ and ratios of $\mathrm{Ca}: \mathrm{P}$ and $\mathrm{SO}_{4}: \mathrm{P} \quad(\mathrm{P}<0.001)$ but with nonsignificant effect on $\mathrm{Na}, \mathrm{K}, \mathrm{Ca}$ and $\mathrm{K}: \mathrm{Na}, \mathrm{K}: \mathrm{Ca}$ and $\mathrm{Ca}: \mathrm{Na}$ ratios (Table 2). Similarly, the addition of $\mathrm{K}$ significantly affected concentrations of leaf $\mathrm{K}$ $(\mathrm{P}<0.05), \mathrm{Na}, \mathrm{SO}_{4}, \mathrm{Ca}(\mathrm{P}<0.01)$ and $\mathrm{K}: \mathrm{Ca}, \mathrm{K}: \mathrm{Na}$ $(\mathrm{P}<0.01), \mathrm{SO}_{4}: \mathrm{P}(\mathrm{P}<0.001)$ and $\mathrm{Ca}: \mathrm{P}$ ratio $(\mathrm{P}<0.05)$ while the effect was non-significant for $\mathrm{P}$ and $\mathrm{Mg}$ concentrations and $\mathrm{Ca}: \mathrm{Na}$ ratio. The interaction of $\mathrm{P}$ and $\mathrm{K}$ significantly affected $\mathrm{Ca}(\mathrm{P}<0.05)$ and $\mathrm{Mg}$ $(\mathrm{P}<0.01)$ concentrations and $\mathrm{Ca}: \mathrm{P}$ and $\mathrm{SO}_{4}: \mathrm{P}$ $(\mathrm{P}<0.01)$ ratios while non-significant on.

Table 1. Wheat yield and the summary of ANOVA on the effect of $\mathrm{K}$ and $\mathrm{P}$ treatments in saline-sodic soils

\begin{tabular}{|c|c|c|c|c|c|}
\hline $\mathrm{P}_{2} \mathrm{O}_{5}$ & $\mathrm{~K}_{2} \mathrm{O}$ & Grain yield & $\begin{array}{c}\% \text { increase over } \\
\text { control }\end{array}$ & Dry matter yield & $\begin{array}{c}\% \text { increase over } \\
\text { control }\end{array}$ \\
\hline ------. & -------- & $\mathrm{Mg} \mathrm{ha}^{-1}$ & & $\mathrm{Mg} \mathrm{ha}^{-1}$ & \\
\hline \multirow[t]{3}{*}{0} & 0 & 1.77 & - & 12.4 & ـ \\
\hline & 75 & 2.66 & 50 & 13.3 & 7 \\
\hline & 150 & 3.33 & 88 & 15.3 & 23 \\
\hline \multirow[t]{3}{*}{60} & 0 & 2.65 & 50 & 12.9 & 4 \\
\hline & 75 & 3.41 & 93 & 14.6 & 18 \\
\hline & 150 & 3.45 & 95 & 15.6 & 26 \\
\hline \multirow[t]{3}{*}{120} & 0 & 3.19 & 80 & 15.3 & 23 \\
\hline & 75 & 3.72 & 110 & 15.9 & 28 \\
\hline & 150 & 3.85 & 118 & 20.0 & 61 \\
\hline \multicolumn{6}{|c|}{ Summary Analysis of Variation } \\
\hline & $\mathrm{SOV}^{1}$ & -------. & ------F value-----. & ----- & \\
\hline & $\mathrm{P}$ & $18.4 * *$ & & $108.0 * * *$ & \\
\hline & $\mathrm{K}$ & $57.2^{* * *}$ & & $17.2 * * *$ & \\
\hline & $\mathrm{P} \times \mathrm{K}$ & $4.55^{*}$ & & NS & \\
\hline
\end{tabular}

$*, * *, * * *=$ Significant at $\mathrm{P}<0.05,0.01$ and 0.001 , respectively and $\mathrm{NS}=$ Not significant

${ }^{1}$ Source of Variation 
Wheat growth...

The chemical composition of wheat leaves indicated that $\mathrm{P}$ concentration decreased from 35.2 to $25.6 \mathrm{mmol}(+) \mathrm{kg}^{-1}$ with $\mathrm{K} 1$ and $\mathrm{K} 2$, respectively at P0, but increased to $59.359 .3 \mathrm{mmol} \mathrm{P} \mathrm{kg}{ }^{-1}$ at P2 when compared with P0 (Table 2). The correlation of $K$ concentrations $[K]$ in leaves was positive with soil $[\mathrm{K}]$, showing increased bioavailability. The $[\mathrm{Na}]$ in leaves reduced to 83.4 , and $85.3 \mathrm{mmol}(+)$ $\mathrm{kg}^{-1}$ at K2 compared with 90.8 and $105.3 \mathrm{mmol}(+)$ $\mathrm{kg}^{-1} \mathrm{Na}$ at $\mathrm{P}_{0}$ and $\mathrm{P} 2$ at $\mathrm{K} 0$. These results suggested that $\mathrm{P}$ enhanced $\mathrm{Na}$ concentrations without $\mathrm{K}$, while $\mathrm{K} 1$ and $\mathrm{K} 2$ at lowered $[\mathrm{Na}]$ in leaves at all $\mathrm{P}$ levels (Table 2). The K:Na ratios in leaves showed a positive correlation $\left(\mathrm{R}^{2}=0.655\right)$ with leaf $[\mathrm{K}]$, while negative correlation $\left(\mathrm{R}^{2}=0.90\right)$ with leaf $[\mathrm{Na}]$ (Fig. $1)$. A higher correlation $\left(\mathrm{R}^{2}=0.851\right)$ of wheat dry matter yield was noted with leaf $\mathrm{K}: \mathrm{Na}$ ratio as compared to wheat grain yield $\left(\mathrm{R}^{2}=0.392\right)$ (Fig. 2).

The addition of diammonium phosphate might have suppressed the $\mathrm{K}$ uptake and $\mathrm{K}: \mathrm{Na}$ ratios in leaves possibly due to the suppressing effect of $\mathrm{NH}_{4}$ on $\mathrm{K}$ (Table 2). However, the leaf $\mathrm{P}$ was more positively correlated with wheat gain yield $\left(\mathrm{R}^{2}=0.53\right)$ than dry matter yield $\left(\mathrm{R}^{2}=0.46\right)$ (Fig. 3$)$.

The [SO4] in leaves increased with the application of $\mathrm{K}_{2} \mathrm{SO}_{4}$ but $\mathrm{P}$ addition tended to suppress $\mathrm{SO}_{4}$. The highest $\mathrm{SO}_{4}$ concentration of $493.8 \mathrm{mmol}(-) \mathrm{kg}^{-1}$ was found at K2P0 (Table 4). That is why a negative correlation $\left(\mathrm{R}^{2}=0.57\right)$ was found between $\mathrm{SO}_{4}: \mathrm{P}$ and the leaf $\mathrm{P}$ concentration (Fig. 4). On the other hand, $\mathrm{SO}_{4}: \mathrm{P}$ ratios in the leaves were increased with $\mathrm{K}_{2} \mathrm{SO}_{4}$ application. Table
HUSSAIN, Z. et al.

5 represents the analysis of variance (ANOVA) showing the influence of $\mathrm{P}$ and $\mathrm{K}$ on the chemical properties of wheat leaves. The $[\mathrm{Mg}]$ was not affected but the $[\mathrm{Ca}]$ and the $\mathrm{Ca}: \mathrm{P}$ ratios increased at $\mathrm{K}_{2} \mathrm{PO}_{4}$ but decreased at higher P levels (P2) in wheat leaves.

\section{Chemical composition of the pre- and post- harvest soil}

Prior to the sowing of seed and the applications of the treatments, the individual soil samples were taken randomly from the whole experimental field at the depth of $0-30 \mathrm{~cm}$ and were thoroughly mixed to produce composite soil samples and were analyzed for the chemical properties (Table 3). Based on high values of $\mathrm{pH}$ $(>8), \mathrm{EC}\left(>4 \mathrm{dS} \mathrm{m}^{-1}\right)$, and SAR $(>13)$, the soils were categorized as saline-sodic. The $[\mathrm{K}]$ and $[\mathrm{P}]$ were found lower than the normal levels $\left(<2 \mathrm{mmol} \mathrm{K} \mathrm{L}^{-1}\right.$ and $<7 \mathrm{mg} \mathrm{P} \mathrm{kg}^{-1}$ ), while $\mathrm{Ca}$ and $\mathrm{Mg}$ were found in moderate quantities. The high $\mathrm{Na}$ concentrations produced high SAR values of soil.

The composite soil samples were taken from each experimental plot after the harvesting of the crop and were analyzed for ionic concentrations (Table 4). The soil $\mathrm{pH}$ was highest in control plots as compared to plots treated with $\mathrm{P} 2$ and $\mathrm{K} 2$, while $\mathrm{EC}_{\mathrm{e}}$ remained unchanged in all plots. The $\mathrm{P}$ treatments significantly $(\mathrm{P}<0.001)$ enhanced $\mathrm{AB}-$ DTPA extractable $[\mathrm{P}]$ but remained non-significant with $\mathrm{K}$ treatments (Table 5).

Table 2. Ionic concentrations and ratios in wheat leaf tissue after $\mathrm{P}$ and $\mathrm{K}$ applications in saline-sodic soils

\begin{tabular}{|c|c|c|c|c|c|c|c|c|c|c|c|}
\hline $\mathrm{P}_{2} \mathrm{O}_{5}$ & $\mathrm{~K}_{2} \mathrm{O}$ & $\mathrm{P}$ & $\mathrm{Na}$ & $\mathrm{K}$ & $\mathrm{Ca}$ & $\mathrm{Mg}$ & $\mathrm{SO}_{4}$ & $\mathrm{~K}: \mathrm{Na}$ & $\mathrm{K}: \mathrm{Ca}$ & $\mathrm{Ca}: \mathrm{P}$ & $\mathrm{SO}_{4}: \mathrm{P}$ \\
\hline \multicolumn{12}{|c|}{----kg ha ${ }^{-1}-----$} \\
\hline \multirow[t]{3}{*}{0} & 0 & 35.2 & 93.1 & 832.7 & 726.7 & 536.7 & 292.7 & 9.04 & 1.15 & 21.0 & 8.56 \\
\hline & 75 & 33.2 & 79.0 & 834.3 & 736.7 & 496.7 & 466.7 & 10.6 & 1.14 & 22.2 & 14.0 \\
\hline & 150 & 25.6 & 77.3 & 890.3 & 780.0 & 536.7 & 493.8 & 11.7 & 1.16 & 30.5 & 19.3 \\
\hline \multirow[t]{3}{*}{60} & 0 & 33.6 & 90.8 & 787.7 & 1030.0 & 633.3 & 287.9 & 8.73 & 0.78 & 30.7 & 8.68 \\
\hline & 75 & 35.0 & 88.0 & 789.0 & 705.0 & 600.0 & 331.7 & 9.10 & 1.13 & 20.4 & 9.51 \\
\hline & 150 & 32.3 & 83.4 & 843.0 & 733.3 & 666.7 & 337.9 & 10.2 & 1.16 & 22.9 & 10.5 \\
\hline \multirow[t]{3}{*}{120} & 0 & 56.9 & 105.3 & 704.7 & 936.7 & 480.0 & 352.4 & 6.76 & 0.75 & 16.6 & 6.29 \\
\hline & 75 & 51.4 & 104.4 & 741.0 & 740.0 & 876.7 & 354.1 & 7.12 & 1.01 & 14.3 & 6.90 \\
\hline & 150 & 59.3 & 85.3 & 847.3 & 666.7 & 750.0 & 438.6 & 10.1 & 1.28 & 11.5 & 7.56 \\
\hline
\end{tabular}

Summary Analysis of Variance (ANOVA) $\mathrm{SOV}^{1}$

-F-ratio

\begin{tabular}{lllllllllll}
$\mathrm{P}$ & $63.4^{* * *}$ & $2.5^{\mathrm{NS}}$ & $4.7^{\mathrm{NS}}$ & $1.0^{\mathrm{NS}}$ & $19.8^{* *}$ & $13.0^{*}$ & $3.2^{\mathrm{NS}}$ & $2.4^{\mathrm{NS}}$ & $38.8^{* *}$ & $37.5^{* * *}$ \\
$\mathrm{~K}$ & $1.1^{\mathrm{NS}}$ & $8.0^{* *}$ & $6.0^{*}$ & $10.1^{* *}$ & $3.5^{\mathrm{NS}}$ & $7.0^{* *}$ & $12.1^{* *}$ & $8.8^{* *}$ & $4.0^{*}$ & $15.9^{* * *}$ \\
$\mathrm{P} x \mathrm{~K}$ & $2.8^{\mathrm{NS}}$ & $0.9^{\mathrm{NS}}$ & $0.6^{\mathrm{NS}}$ & $3.6^{*}$ & $6.1^{*}$ & $2.2^{\mathrm{NS}}$ & $0.6^{\mathrm{NS}}$ & $2.6^{\mathrm{NS}}$ & $9.0^{* * *}$ & $7.0^{* *}$ \\
\hline
\end{tabular}

$*, * *, * * *=$ Significant at $\mathrm{P}<0.05,0.01$ and 0.001 , respectively and $\mathrm{NS}=$ Not significant

${ }^{1}$ Source of Variation 
Table 3. Chemical composition of saline-sodic soil before cultivation

\begin{tabular}{|c|c|c|c|}
\hline Soil Properties & Units & Range & Mean \pm SD \\
\hline $\mathrm{pH}$ & - & $8.2-8.8$ & $8.6 \pm 0.2$ \\
\hline $\mathrm{EC}_{\mathrm{e}}$ & $\mathrm{dS} \mathrm{m}^{-1}$ & $4.2-9.4$ & $5.5 \pm 1.5$ \\
\hline $\mathrm{P}$ & $\mathrm{mg} \mathrm{kg}^{-1}$ & $5.9-11.2$ & $7.7 \pm 1.5$ \\
\hline $\mathrm{Na}$ & $\operatorname{mmol}(+) \mathrm{L}^{-1}$ & $32.6-64.1$ & $39.4 \pm 9.8$ \\
\hline K & $\operatorname{mmol}(+) \mathrm{L}^{-1}$ & $0.2-0.6$ & $0.3 \pm 0.1$ \\
\hline $\mathrm{Ca}+\mathrm{Mg}$ & $\mathrm{mmol}(+) \mathrm{L}^{-1}$ & $14.0-35.7$ & $20.6 \pm 6.7$ \\
\hline $\mathrm{Cl}$ & mmol (-) $\mathrm{L}^{-1}$ & $23.6-58.5$ & $31.3 \pm 10.7$ \\
\hline $\mathrm{SO}_{4}$ & $\operatorname{mmol}(+) \mathrm{L}^{-1}$ & $3.2-6.2$ & $4.2 \pm 1.1$ \\
\hline SAR & - & $10.4-15.2$ & $12.4 \pm 1.4$ \\
\hline $\mathrm{CaCO}_{3}$ & $\%$ & $15.3-19.4$ & $17.5 \pm 1.2$ \\
\hline
\end{tabular}

The addition of $\mathrm{P}$ increased AB-DTPA extractable $\mathrm{P}$ and also the ratios of $\mathrm{Ca}: \mathrm{P}, \mathrm{Cl}: \mathrm{P}$ and $\mathrm{SO}_{4}: \mathrm{P}$, while the soil $\mathrm{pH}$, concentrations of $\mathrm{Na}, \mathrm{K}$, $\mathrm{Ca}, \mathrm{SO}_{4}, \mathrm{SAR}$ and ratios of $\mathrm{Na}: \mathrm{K}, \mathrm{Na}: \mathrm{Ca}$, and $\mathrm{Ca}: \mathrm{K}$ were influenced by $\mathrm{K}$. The interaction of $\mathrm{P} \times \mathrm{K}$ nonsignificantly affected all parameters with the exception of $\mathrm{Cl}: \mathrm{P}$ and $\mathrm{SO}_{4}: \mathrm{P}$ ratios (Table 5).

The $[\mathrm{K}]$ remained inconsistent at $\mathrm{P} 1$ and $\mathrm{P} 2$ alone, when averaged across $(n=9) P$ levels but increased with combined $\mathrm{P}$ and $\mathrm{K}$ treatments (Table 4). The $[\mathrm{K}]$ in soil enhanced from 0.41 to 0.57 at $\mathrm{P} 0$, 0.36 to 0.56 at $\mathrm{P} 1$, and 0.42 to $0.65 \mathrm{mmol}(+) \mathrm{L}^{-1}$ at $\mathrm{P} 2$ with $\mathrm{K} 2$, respectively. It demonstrated that $\mathrm{P}$ addition did not affect soil $[\mathrm{K}]$ but with the addition of $\mathrm{K}$ treatments. The [Na] was found relatively higher at $\mathrm{P} 0 \mathrm{~K} 0, \mathrm{P} 2 \mathrm{~K} 0$, and $\mathrm{P} 0 \mathrm{~K} 2$, but decreased significantly $(\mathrm{P}<0.05)$ at $\mathrm{P} 1 \mathrm{~K} 1$ and $\mathrm{P} 2 \mathrm{~K} 2$ as compared to control (Table 4 and 5). Similarly, $\mathrm{Na}: \mathrm{K}$ ratios were significantly $(\mathrm{P}<0.001)$ decreased from 87.8 to 43.7 at higher $\mathrm{P}$ and $\mathrm{K}$, as compared with control (Table 4). A negative correlation $\left(R^{2}=0.637\right)$ was found between soil Na:K ratios and soil [K] (Fig. 5).

The sodium adsorption ratio (SAR) was significantly $(P<0.001)$ influenced by $\mathrm{K}$ application (Table 4) and hence a negative correlation $\left(\mathrm{R}^{2}=0.631\right)$ was observed between SAR values and soil $[\mathrm{K}]$ in saturation extract (Fig. 5). The elevated [Ca] at P0K2 seemed to have decreased $\mathrm{Na}$ concentrations as well as the SAR to 9.6 as compared to control. The SAR values showed a decreasing tendency to 8.80 and 10.6 and to 9.42 and 8.15 with $\mathrm{P}$ levels at $\mathrm{K} 1$ and $\mathrm{K} 2$ respectively, $\mathrm{P} 1 \mathrm{~K} 2$ and $\mathrm{P} 2 \mathrm{~K} 2$ as compared to control SAR values (12.0). Such trends indicated that $P$ treatments at higher K levels substantially decreased SAR of the soil.

The concentrations of $\mathrm{Ca}$ were not influenced by $\mathrm{P}$, but the ratio of $\mathrm{Ca}: \mathrm{P}$ in soil were significantly $(\mathrm{P}<0.001)$ reduced (Table 5). Similarly, $\mathrm{SO}_{4}: \mathrm{P}$ also decreased significantly $(\mathrm{P}<0.001)$, but $\mathrm{P}$ treatments did not influence the concentrations of $\mathrm{Cl}, \mathrm{CO}_{3}$, and $\mathrm{HCO}_{3}$ (Table 5). A negative correlation $\left(\mathrm{R}^{2}=0.89\right)$ was observed between soil $\mathrm{SO}_{4}: \mathrm{P}$ and the $\mathrm{P}$ treatments (Fig. 6). Similarly, there was a negative correlation $\left(\mathrm{R}^{2}=0.73\right)$ between Cl:P and AB-DTPA extractable soil P (Fig. 6). 
Table 4. Chemical composition of saturated extracts of post-harvest (wheat) silty clay loams saline-sodic soils after $\mathrm{P}$ and $\mathrm{K}$ application

\begin{tabular}{|c|c|c|c|c|c|c|c|c|c|c|c|c|c|c|c|c|c|c|c|c|}
\hline $\mathrm{P}_{2} \mathrm{O}_{5}$ & $\mathrm{~K}_{2} \mathrm{O}$ & $\mathrm{pH}$ & $\mathrm{EC}_{\mathrm{e}}$ & $\mathrm{P}$ & SAR & $\mathrm{Na}$ & $\mathrm{K}$ & $\mathrm{Ca}$ & $\mathrm{Mg}$ & $\mathrm{Cl}$ & $\mathrm{SO}_{4}$ & $\mathrm{CO}_{3}$ & $\mathrm{HCO}_{3}$ & Na:K & $\mathrm{Na}: \mathrm{Ca}$ & $\mathrm{Ca}: \mathrm{K}$ & Ca:P & $\mathrm{Cl}: \mathrm{P}$ & $\mathrm{Cl}: \mathrm{SO}_{4}$ & $\mathrm{SO}_{4}: \mathrm{P}$ \\
\hline $\begin{array}{l}---k g \\
-\end{array}$ & $\mathrm{ha}^{-1}$ - & & $\begin{array}{l}\mathrm{dS} \\
\mathrm{m}^{-1}\end{array}$ & $\mathrm{mg} \mathrm{kg}_{-1}$ & & & & $--m$ & $\mathrm{nol} \mathrm{( \pm}$ & $\mathrm{L}^{-1}-$ & - & 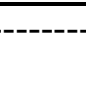 & ---- & & & & & & & \\
\hline \multirow[t]{3}{*}{0} & 0 & 8.6 & 5.4 & 4.6 & 12.0 & 36.5 & 0.4 & 10.0 & 8.4 & 42.0 & 7.3 & 1.5 & 2.6 & 87.8 & 3.66 & 24.1 & 69.1 & 284.4 & 5.6 & 50.4 \\
\hline & 75 & 8.6 & 5.2 & 6.1 & 10.2 & 29.6 & 0.5 & 9.83 & 7.2 & 31.4 & 7.9 & 1.4 & 2.9 & 57.9 & 3.11 & 18.8 & 49.7 & 164.0 & 4.0 & 40.4 \\
\hline & 150 & 8.4 & 5.8 & 6.2 & 9.6 & 32.3 & 0.6 & 12.2 & 11.0 & 50.2 & 9.1 & 1.6 & 3.2 & 57.2 & 2.71 & 21.3 & 60.4 & 247.9 & 5.4 & 45.3 \\
\hline \multirow[t]{3}{*}{60} & 0 & 8.6 & 5.0 & 8.3 & 12.1 & 31.8 & 0.3 & 8.8 & 5.2 & 41.9 & 7.6 & 2.0 & 2.8 & 89.5 & 3.62 & 24.7 & 32.8 & 154.1 & 5.5 & 28.4 \\
\hline & 75 & 8.4 & 4.5 & 6.0 & 8.8 & 26.0 & 0.4 & 9.0 & 8.6 & 34.9 & 8.2 & 1.4 & 3.0 & 71.2 & 2.96 & 24.5 & 48.1 & 193.0 & 4.4 & 43.9 \\
\hline & 150 & 8.4 & 5.1 & 7.5 & 9.4 & 29.5 & 0.6 & 11.2 & 8.5 & 41.4 & 8.4 & 1.5 & 2.7 & 53.5 & 2.71 & 19.9 & 47.3 & 172.5 & 4.8 & 35.8 \\
\hline \multirow[t]{3}{*}{120} & 0 & 8.6 & 5.4 & 9.6 & 11.5 & 35. & 0.4 & 10.9 & 7.8 & 37.1 & 8.0 & 1.7 & 3.3 & 84.6 & 3.27 & 26.1 & 35.2 & 121.7 & 4.5 & 26.1 \\
\hline & 75 & 8.4 & 5.8 & 9.4 & 10.6 & 34.1 & 0.6 & 10.7 & 9.8 & 46.8 & 9.3 & 1.8 & 2.8 & 58.9 & 3.18 & 18.6 & 35.5 & 155.4 & 4.9 & 31.0 \\
\hline & 150 & 8.2 & 5.5 & 11.7 & 8.1 & 28.3 & 0.7 & 15.1 & 9.9 & 34.7 & 9.4 & 1.4 & 3.1 & 43.7 & 2.00 & 23.0 & 40.2 & 92.1 & 3.6 & 25.1 \\
\hline
\end{tabular}

Table 5. Summary analysis of variance (ANOVA) on the effect of $\mathrm{P}$ and $\mathrm{K}$ on the ionic concentrations and ratios of saturation extracts of silty clay loam saline-sodic Table

\begin{tabular}{|c|c|c|c|c|c|c|c|c|c|c|c|c|c|}
\hline \multirow[b]{2}{*}{ SOV } & \multicolumn{13}{|c|}{ Variables Analyzed } \\
\hline & $\mathrm{pH}$ & AB-DTPA P & $\mathrm{Na}$ & $\mathrm{K}$ & $\mathrm{Ca}$ & $\mathrm{SO}_{4}$ & SAR & $\mathrm{Na}: \mathrm{K}$ & $\mathrm{Na}: \mathrm{Ca}$ & $\mathrm{Ca}: \mathrm{K}$ & $\mathrm{Ca}: \mathrm{P}$ & $\mathrm{Cl}: \mathrm{P}$ & $\mathrm{SO}_{4}: \mathrm{P}$ \\
\hline & -------- & & & & & & & & & & & & \\
\hline $\mathrm{P}$ & $0.32^{\mathrm{NS}}$ & $92.4 * * *$ & $5.02^{\mathrm{NS}}$ & $3.85^{\mathrm{NS}}$ & $1.38^{\mathrm{NS}}$ & $1.09^{\mathrm{NS}}$ & $0.57^{\mathrm{NS}}$ & $3.47^{\mathrm{NS}}$ & $0.81^{\mathrm{NS}}$ & $0.52^{\mathrm{NS}}$ & $12.7^{*}$ & $10.9^{* *}$ & $134.3^{* * *}$ \\
\hline K & $7.12^{*}$ & $2.17^{\mathrm{NS}}$ & $7.43 * *$ & $26.2 * * *$ & $4.62 *$ & $5.90 *$ & $33.2 * * *$ & $38.6 * * *$ & $12.8 * *$ & $4.14 *$ & $0.49^{\mathrm{NS}}$ & $0.28^{\mathrm{NS}}$ & $0.81^{\mathrm{NS}}$ \\
\hline $\mathrm{P} \times \mathrm{K}$ & $0.61^{\mathrm{NS}}$ & $2.51^{\mathrm{NS}}$ & $2.58^{\mathrm{NS}}$ & $1.45^{\mathrm{NS}}$ & $0.20^{\mathrm{NS}}$ & $0.33^{\mathrm{NS}}$ & $2.83^{\mathrm{NS}}$ & $1.01^{\mathrm{NS}}$ & $0.80^{\mathrm{NS}}$ & $1.60^{\mathrm{NS}}$ & $2.13^{\mathrm{NS}}$ & $3.03 *$ & $4.04 *$ \\
\hline
\end{tabular}

$*, * *, * *=$ Significant at $\mathrm{P}<0.05,0.01$ and 0.001 , respectively and $\mathrm{NS}=$ Not significant 
(a)

(b)
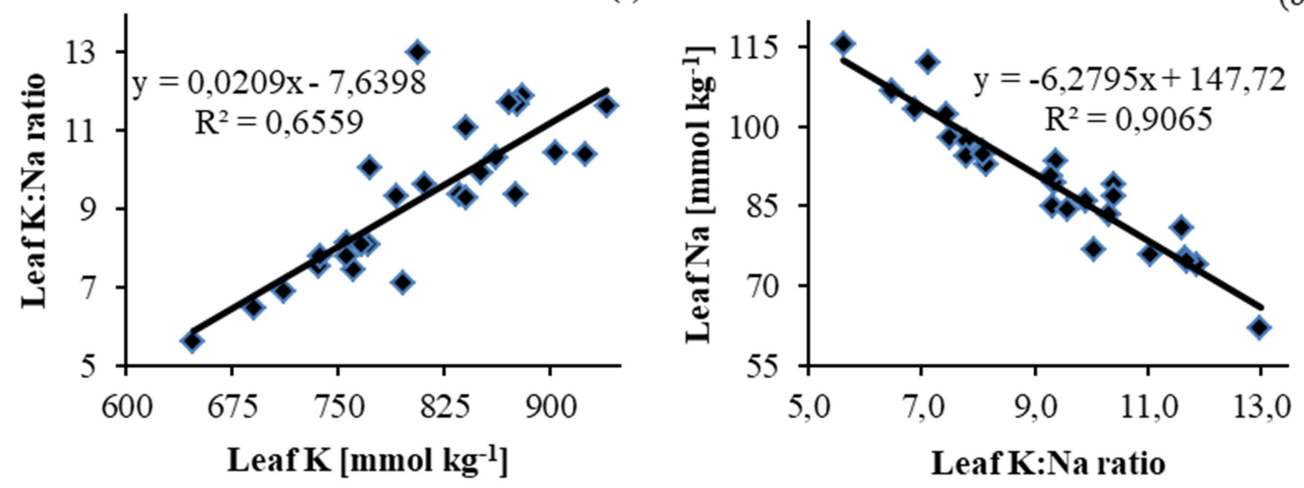

Figure 1. Leaf $K: \mathrm{Na}$ ratio in relation to leaf $[\mathrm{K}](\mathrm{a})$ and leaf $[\mathrm{Na}]$ in relation to leaf $\mathrm{K}: \mathrm{Na}$ ratio (b) in salinesodic soil

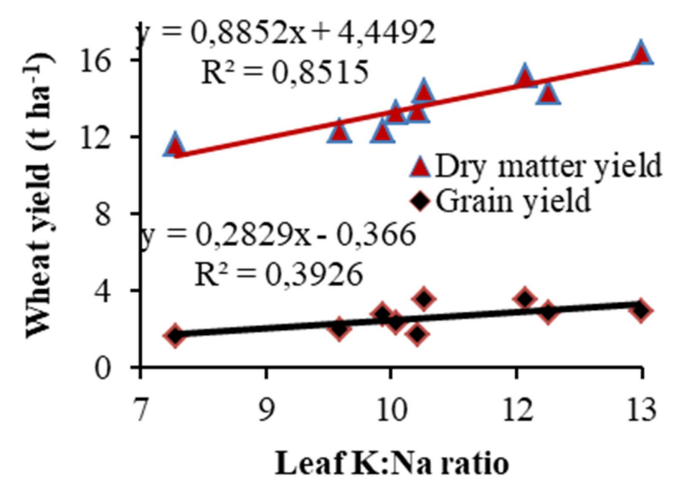

Figure 2. Grain and dry matter yield of wheat in relation to $\mathrm{K}: \mathrm{Na}$ ratio in leaf tissue of wheat grown in $\mathrm{K}_{2} \mathrm{SO}_{4}$ treated $(n=9)$ saline-sodic soil

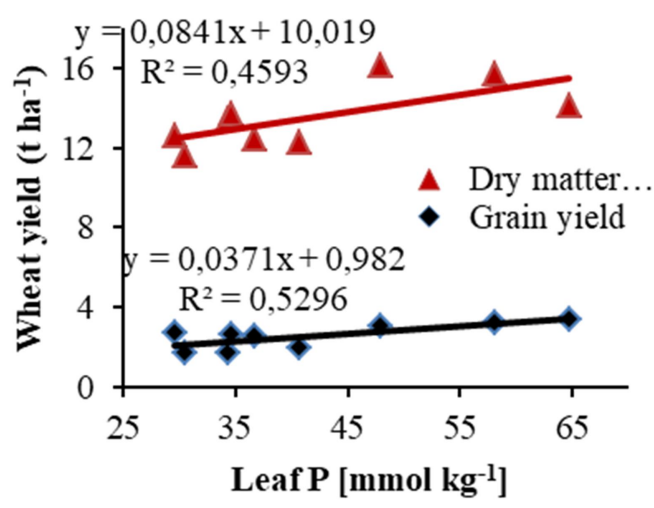

Figure 3. Grain and dry matter yield in relation to $\mathrm{P}$ concentrations in leaf tissue of wheat grown on $\mathrm{P}_{2} \mathrm{O}_{5}$ treated $(n=9)$ saline-sodic soils 


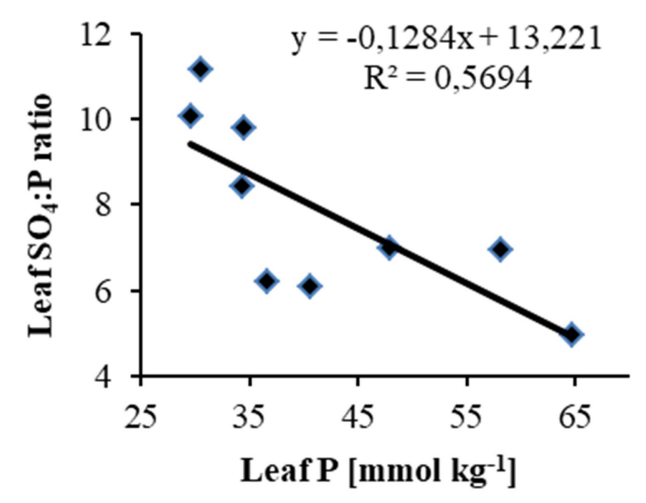

Figure 4. Leaf $\mathrm{SO}_{4}: \mathrm{P}$ ratios in relation to $[\mathrm{P}]$ leaf tissue of wheat grown on $\mathrm{P}_{2} \mathrm{O}_{5}$ treated (n=9) saline-sodic soil

(a)

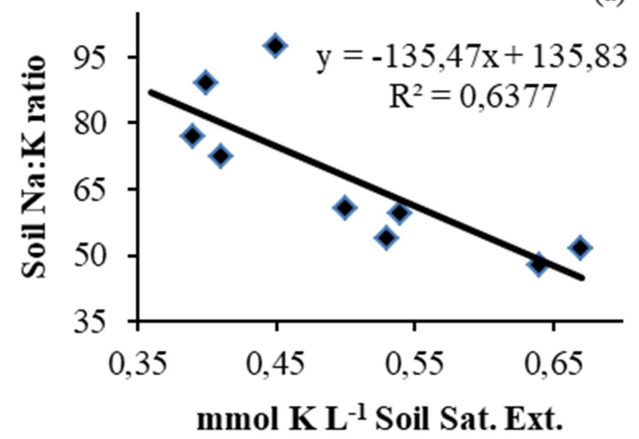

(b)

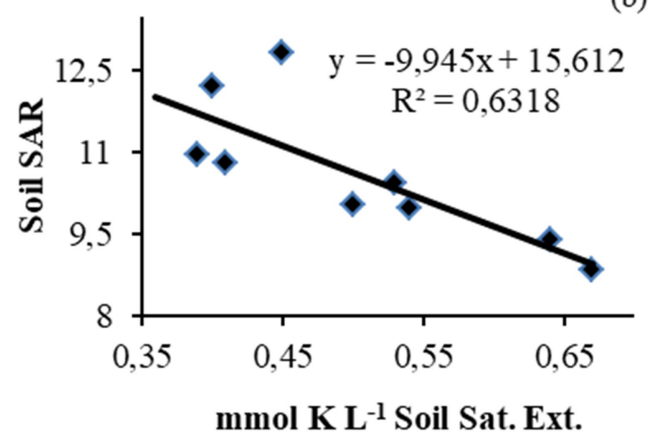

Figure 5. Soil Na:K ratio and $S A R$ in relation to $[K]$ in saturated extracts in $\mathrm{K}_{2} \mathrm{O}$ treated (n=9) saline-sodic soil

(a)
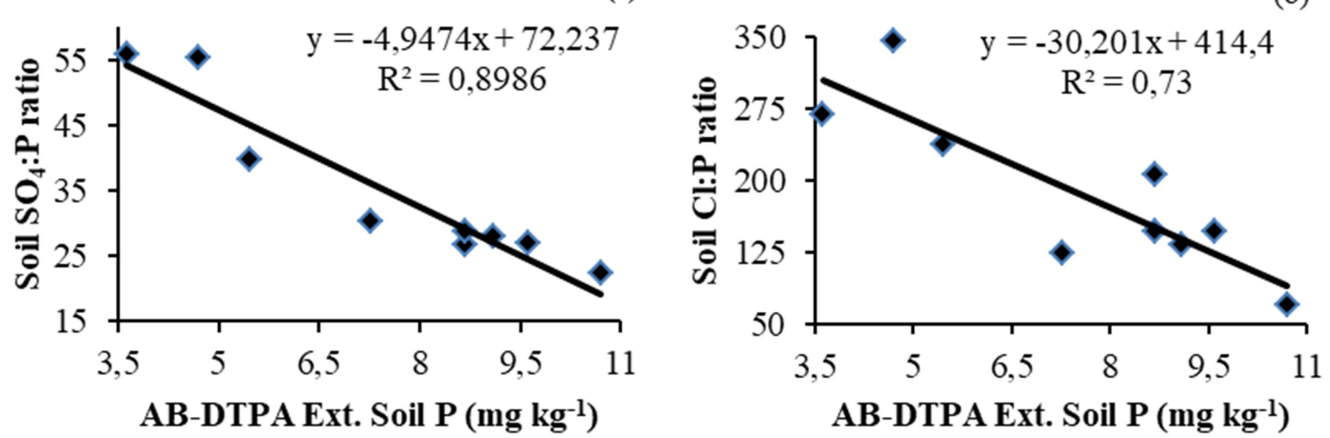

Figure 6. Soil $\mathrm{SO}_{4}: \mathrm{P}(\mathrm{a})$ and $\mathrm{Cl}: \mathrm{P}$ ratios $(\mathrm{b})$ in relation to AB-DTPA ext. soil $\mathrm{P}$ in $\mathrm{P}_{2} \mathrm{O}_{5}$ treated $(\mathrm{n}=9)$ saline- 


\section{DISCUSSION}

\section{Wheat growth as influenced by $P$ and $K$ application}

The findings of this study indicate a potential contribution of $\mathrm{P}$ and $\mathrm{K}$ to crop nutrition and growth. The salinity and sodicity are responsible to disturb the nutrient balance of the crops, resulting in stunted growth and poor yields. The deficiency of $\mathrm{P}$ and $\mathrm{K}$ nutrition and/or the competition of these nutrients with other ions restricts their uptake by plants under salt-affected soil conditions. The optimization of $\mathrm{P}$ and $\mathrm{K}$ fertilization can improve plant metabolism to tolerate salt stress resulting in higher yields of crops. In the present study, the grain yield of wheat increases consistently with increasing $\mathrm{P}$ and $\mathrm{K}$ levels in salt-affected soils. The combined $\mathrm{P}$ and $\mathrm{K}$ applications resulted in the highest grain and dry matter yields when compared with control. Phosphorus had a greater effect on grain yield as compared to the effect of $\mathrm{K}$ in saline-sodic soil. SINGH et al. (2006) confirmed the positive response of wheat to supplementary $\mathrm{P}$ in the presence of $\mathrm{Na}$ which resulted in higher grain yield at higher salt concentrations.

Relatively lower wheat yields at control treatments are caused by the effect of Na-salts, while increases in yield are associated with high $\mathrm{K}$ uptake by wheat (MEHDI et al., 2007). KRISHNASAMY et al. (2014) examined four wheat cultivars under varying $\mathrm{K}$ and $\mathrm{Na}$ levels and reported that high $\mathrm{Na}$ concentration reduced wheat growth of all cultivars at low $\mathrm{K}$, but adequate $\mathrm{K}$ maintained a higher number of tillers in most cultivars.

\section{Nutrient uptake and wheat yield}

Analysis of leaf tissues is important to monitor nutrient deficiencies and uptake under applied treatments, in saline-sodic soil conditions. The application of $\mathrm{P}$ and $\mathrm{K}$ treatments influenced the chemical composition of the leaf. Plants $\mathrm{P}$ concentrations $[\mathrm{P}]$ were increased with $\mathrm{P}$ application. Similar results were reported by NIAZI et al. (1990). Also, the leaf K concentrations were significantly increased with the application of $\mathrm{K}_{2} \mathrm{SO}_{4}$ which helped to alleviate crop stress. There was a positive correlation between leaf $\mathrm{K}$ and soil $\mathrm{K}$ concentrations. The addition of $\mathrm{K}$ reduced leaf [Na] while increasing trend in $[\mathrm{Na}]$ was observed when $\mathrm{P}$ was applied alone. The depressing effect of $\mathrm{K}$ fertilizer on leaf $[\mathrm{Na}]$ in wheat, sugar beet, and maize crops is reported by HUSSAIN et al. (2015).
A positive correlation $\mathrm{K}: \mathrm{Na}$ and leaf $[\mathrm{K}]$ and with the DM yield of wheat suggested a depressed $\mathrm{Na}$ uptake which promoted the yield of wheat in the present study. If the whole plant parts are compared, the leaves and stem contain much higher concentrations of $\mathrm{K}$ than roots or grains (NABIPOUR et al., 2007). Uptake and accumulation of $\mathrm{K}$ by plant roots are strongly inhibited by high $\mathrm{Na}$ concentrations (NETONDO et al., 2004). The K supply enhanced [K] and $\mathrm{K}: \mathrm{Na}$ in leaves and shoot of all wheat cultivars, and high net photosynthesis rate in fully expanded leaves of wheat than at low K levels (KIRSHNASAMY et al., 2014).

A distinct relationship between wheat grain yield and the $[\mathrm{P}]$ in leaves was observed. The $\mathrm{SO}_{4}$ uptake was depressed by $\mathrm{P}$ application but $\mathrm{K}$ treatments as $\mathrm{K}_{2} \mathrm{SO}_{4}$ enhanced concentrations of $\mathrm{SO}_{4}$ ratios in leaf tissue. The $\mathrm{Ca}$ uptake was enhanced with $\mathrm{K}$ at $\mathrm{P} 0$ but inhibited at $\mathrm{P} 1$ and $\mathrm{P} 2$. There was no difference in $\mathrm{Ca}: \mathrm{P}$ at $\mathrm{P} 0 \mathrm{~K} 0$ and $\mathrm{K} 1$, but increased at $\mathrm{K} 2$, substantially with increasing $\mathrm{P}$ levels. A complex interaction process may be involved among $\mathrm{Ca}, \mathrm{K}, \mathrm{SO}_{4}$, and $\mathrm{PO}_{4}$ in the soil which affected uptake and inhibition of ions by plants. Application of $\mathrm{K}_{2} \mathrm{SO}_{4}$ enhanced $\mathrm{Ca}$ concentrations without $\mathrm{P}$, which might have favored the development of soluble complexes of $\mathrm{CaSO}_{4}$ in saline soils supporting $\mathrm{Ca}$ uptake by plants (SPOSITO, 1989). Results suggest that interactions of applied $\mathrm{P}$ and $\mathrm{K}$ fertilizers with $\mathrm{Na}, \mathrm{Ca}, \mathrm{Cl}$ and $\mathrm{SO}_{4}$ mitigate the influence of salts and promote crop growth in saline-sodic soils.

\section{Influence on soil chemical composition}

Phosphorus is rendered insoluble and immobilized in a saline soil solution because of the effect of high ionic strength (NISTE et al., 2014). In our study, the application of $\mathrm{P}$ had a significant effect on soil $[\mathrm{P}]$ as well as $\mathrm{Ca}: \mathrm{P}, \mathrm{Cl}: \mathrm{P}$, and $\mathrm{SO}_{4}: \mathrm{P}$ ratios. Application of $\mathrm{K}$ had a significant influence on $\mathrm{pH}$, and concentrations of $\mathrm{Na}, \mathrm{K}, \mathrm{Ca}, \mathrm{SO}_{4}, \mathrm{SAR}$ values and ratios of $\mathrm{Na}: \mathrm{K}, \mathrm{Na}: \mathrm{Ca}$, and $\mathrm{Ca}: \mathrm{K}$. Concentrations of $\mathrm{K}$ in soil remained unchanged with the addition of $\mathrm{P}$ alone but increased at $\mathrm{K} 1$ and $\mathrm{K} 2$. The soil $\mathrm{P}$ availability increased with $\mathrm{P}$ application which supported wheat yield, but it depressed other macronutrients like $\mathrm{K}$ and $\mathrm{N}$, as reported in various studies (HAO et al., 2005). The $\mathrm{P}$ and $\mathrm{K}$ reduced $\mathrm{Na}: \mathrm{K}$ ratios when compared with control. A negative correlation $\left(\mathrm{R}^{2}=0.63\right)$ was found between soil $[\mathrm{K}]$ and soil Na:K ratios. Adding higher levels of $\mathrm{K}$ and $\mathrm{P}$ significantly lowered $\mathrm{Na}: \mathrm{K}$ ratios as compared to control. The salt-tolerant crops tend to retain high $[\mathrm{K}]$ while excluding $\mathrm{Na}$ from the 
shoots (FLOWERS; HAJIBAGHERI, 2001). Moderate native $[\mathrm{K}]$ sometimes even becomes unavailable to plants because of high competition with $\mathrm{Na}$ in soils. Therefore, $\mathrm{K}$ application to such soil may enhance its selectivity and bioavailability for the plants. Application of $\mathrm{K}$ to a highly saline soil promoted dry matter yield of barley, supported high accumulation of $\mathrm{K}$ and maintained lower $\mathrm{Na}: \mathrm{K}$ ratio which also suggested positive role of $\mathrm{K}$ in mitigating salt stress (ENDRIS; MOHAMMAD, 2007).

The $\mathrm{K}$ treatment also promoted higher $\mathrm{Ca}$ concentrations in soil and reduced $\mathrm{Na}$ when compared with control. Similarly, the SAR values were decreased with $\mathrm{P}$ at higher $\mathrm{K}$ treatments. The application of $\mathrm{K}$ as $\mathrm{K}_{2} \mathrm{SO}_{4}$ increased $\mathrm{SO}_{4}$ in soil but the application of $\mathrm{P}$ lowered $\mathrm{SO}_{4}: \mathrm{P}$ ratios in soil. A negative correlation $\left(\mathrm{R}^{2}=0.898\right)$ was found between soil $\mathrm{SO}_{4}: \mathrm{P}$ ratios and the $\mathrm{P}$ treatment. NISTE et al. (2014) reported that $\mathrm{Cl}$ inhibits more $\mathrm{N}$ than $\mathrm{SO}_{4}$, therefore the application of $\mathrm{S}$ as $\mathrm{K}_{2} \mathrm{SO}_{4}$ to saltaffected soils improves concentrations of N, P, and $\mathrm{K}$ which supports higher wheat yield. Application of gypsum in combination with $\mathrm{K}$ fertilizers to salinesodic soils irrigated with saline water amended soil chemical properties and facilitated wheat growth. The correlation between soil $\mathrm{Cl}: \mathrm{P}$ ratios and soil $\mathrm{P}$ was found negative $\left(\mathrm{R}^{2}=0.73\right)$. The $\mathrm{Cl}$ toxicity of salt-affected soils was minimized with $\mathrm{P}$ treatment.

\section{CONCLUSIONS}

The study demonstrates that the addition of $\mathrm{P}$ and $\mathrm{K}$ fertilizers enhanced both grain and dry matter yields of wheat. Effect of $\mathrm{P}$ treatment on grain yield was more profound than $\mathrm{K}$ application but dry matter yield increased more with $\mathrm{K}$ when compared with control. Whereas the combined effect of high $\mathrm{P}$ and $\mathrm{K}$ dozes $\left(120 \mathrm{~kg} \mathrm{P}_{2} \mathrm{O}_{5} \mathrm{ha}^{-1}\right.$ and $150 \mathrm{~kg} \mathrm{~K} \mathrm{O}^{-1}$ ) was more pronounced in grain yield showing $118 \%$ increases when compared with $\mathrm{P}$ or $\mathrm{K}$ alone. The $\mathrm{P}$ and $\mathrm{K}$ improved leaf $\mathrm{K}, \mathrm{P}, \mathrm{Ca}$, and $\mathrm{SO}_{4}$ concentrations, increased $\mathrm{K}: \mathrm{Na}$ and $\mathrm{SO} 4: \mathrm{P}$ ratios while reducing $\mathrm{Na}$ and $\mathrm{Cl}$ concentrations when compared with control values. The dry matter yield correlated more positively with $\mathrm{K}$ : $\mathrm{Na}$ ratios in leaf. The applied $\mathrm{K}$ amended soil $\mathrm{K}, \mathrm{Ca}, \mathrm{SO}_{4}$ concentrations, and reduced $\mathrm{Na}$ levels, SAR, and $\mathrm{Na}: \mathrm{K}$ in saline-sodic soils, while $\mathrm{P}$ application improved soil $\mathrm{P}$ while decreasing the $\mathrm{Cl}$ levels in the soil. This study suggested that applications of $\mathrm{K}$ and $P$ fertilizers bring positive changes in soil-plantnutrients dynamics and hence plant yield in a saline environment.

\section{ACKNOWLEDGEMENT}

This study was partially funded by the Joint Research Program of Arid Land Research Center, Tottori University, Japan (Grant No. 29GR1001).

RESUMO: A deficiência de nutrientes é um fator limitante em solos salino-sódicos, resultando em baixa produção agrícola. $\mathrm{O}$ estudo investigou a resposta do trigo ao $\mathrm{P}$ e $\mathrm{K}$ adicionados ao solo. $\mathrm{O} \mathrm{K}$ foi aplicado em 0 (K0), 75 (K1), 150 (K2) kg K2 $\mathrm{K} \mathrm{ha}^{-1}$ como $\mathrm{K}_{2} \mathrm{SO}_{4}$ e em (0 (P0), 60 (P1), 120 (P2) kg $\mathrm{P}_{2} \mathrm{O}_{5}$ ha $^{-1}$ como $\left(\mathrm{NH}_{4}\right)_{2} \mathrm{HPO}_{4}$ em três repetições sob delineamento de blocos completos casualizados (RCB) de dois fatores. Ambos os tratamentos aumentaram significativamente o rendimento de grãos de trigo (118\%) e de matéria seca (60\%) em P2K2 em comparação com o controle. Os tratamentos com P afetaram significativamente o P foliar, $\mathrm{Mg}, \mathrm{SO}_{4}$, as razões $\mathrm{Ca}: \mathrm{P}, \mathrm{SO}_{4}: \mathrm{P}$ e o $\mathrm{P}$ do solo, e as razões $\mathrm{Ca}: \mathrm{P}, \mathrm{Cl}: \mathrm{P}_{\text {e }} \mathrm{SO}_{4}: \mathrm{P}$, enquanto $\mathrm{K}$ no $\mathrm{K}$ foliar, $\mathrm{Na}, \mathrm{Ca}$, concentração de $\mathrm{SO}_{4}$, razões $\mathrm{K}: \mathrm{Na}, \mathrm{K}: \mathrm{Ca}$, SO4:P, Ca:P e pH do solo, $\mathrm{Na}, \mathrm{K}, \mathrm{Ca}$, concentrações de $\mathrm{SO}_{4}$, SAR, razões Na:K, Ca:K e Na:Ca. O Na da folha foi reduzido para 85,3 mmol (+) $\mathrm{kg}^{-1}$ em K2 em comparação com $105,3 \mathrm{mmol}(+) \mathrm{kg}^{-1}$ em P2K0. Correlação negativa $\left(\mathrm{R}^{2}=0,906\right)$ do $\mathrm{K}: \mathrm{Na}$ na folha foi encontrada com a concentração de Na na folha. A correlação da matéria seca foi maior $\left(R^{2}=0,851\right)$ com a relação K:Na da folha do que rendimento de grãos $\left(\mathrm{R}^{2}=0,392\right)$. Conclui-se que a adição de $\mathrm{K}$ e $\mathrm{P}$ apresenta efeitos benéficos na melhoria da nutrição da cultura e na produtividade do trigo em solo salino-sódico.

PALAVRAS-CHAVE: Crescimento do trigo. P. K. Região semiárida. Região árida. Solo salinosódico.

\section{REFERENCES}

ALI, Y.; ASLAM, Z.; ASHRAF, M. Y.; TAHIR, G. R. Effect of salinity on chlorophyll concentration, leaf area, yield, and yield components of rice genotypes grown under saline environments. International Journal of Environmental Science and Technology, v. 1, p. 229-234, 2004. http://doi.org/10.1007/BF03325881 
CUIN, T. A.; BETTS, S. A.; CHALMANDRIER, R.; SHABALA, S. A root's ability to retain $\mathrm{K}^{+}$correlates with salt tolerance in wheat. Journal of Experimental Botany, 59, 2697-2706, 2008.

https://doi.org/10.1093/jxb/ern128

ENDRIS, S.; MOHAMMAD, M. J. Nutrient acquisition and yield response of barley exposed to salt stress under different levels of potassium nutrition. International Journal of Environmental Science and Technology, v. 4, p. 323-330, 2007. http://doi.org/10.1007/BF03326289

FLOWERS, T. J.; HAJIBAGHERI, M. A. Salinity tolerance in Hordeum vulgare: ion concentrations in root cells of cultivars differing in salt tolerance. Plant and Soil, v. 231, p. 1-9, 2001.

http://doi.org/10.1023/A:1010372213938

GARG, B. C.; GUPTA, I. C. Physiology of salt tolerance of arid-zone crops. IV. Rapeseed and Indian mustard, Central Arid Zone Research Institute, Jodhpur, India. Current Agricultural Research Journal, v. 22, p. 1-2, 1998.

HAO, M. D.; FAN, J.; WEI, X. R.; PEN, L. F.; LAI, L. Effect of fertilization on soil fertility and wheat yield of dryland in the Loess Plateau. Pedosphere, v. 15, p. 189-195, 2005. ISSN: 1002-0160

HAIDER, M. Z.; HOSSAIN, M. Z. Impact of salinity on livelihood strategies of farmers. Journal of Soil Science and Plant Nutrition, v. 13, p. 417-431, 2013. http://dx.doi.org/10.4067/S0718-95162013005000033.

HUSSAIN, Z.; KHATTAK, R. A.; IRSHAD, M.; MAHMOOD, Q. Sugar beet (Beta vulgaris L.) response to diammonium phosphate and potassium sulfate under saline-sodic conditions. Soil Use and Management, 30 , 320-327, 2014. http://doi.org/10.1111/sum.12132

HUSSAIN, Z.; KHATTAK, R. A.; FAREED, I.; IRSHAD, M.; MAHMOOD, Q. Interaction of phosphorus and potassium on maize (Zea mays L.) under saline-sodic soil conditions. Journal of Agricultural Science, v. 7, p. 66-78, 2015. http://dx.doi.org/10.5539/jas.v7n3p66

JORDAN, M. M.; NAVARRO-PEDRENO, J.; GARCIA-SANCHEZ, E.; MATEU, J.; JUAN, P. Spatial dynamics of soil salinity under arid and semi-arid conditions: geological and environmental implications. Environmental Geology, 45, 448-456, 2004. http://doi.org/10.1007/s00254-003-0894-y

KHAN, A.; AHMAD, I.; SHAH, A.; AHMAD, F.; GHANI, A; NAWAZ, M.; SHAHEEN, F.; FATIMA, H. U.; PERVAIZ, F.; JAVED, S.; HAYAT, F.; NAWAZ, H.; ZUBAIR, R. Amelioration of salinity stress in wheat (Triticum aestivum L) by foliar application of phosphorus. Phyton, v. 82, p. 281-287, 2013.

KRISHNASAMY, K.; BELL, R.; MA, Q. Wheat responses to sodium vary with potassium use efficiency of cultivars. Frontiers in Plant Science, v. 5, p. 1-10, 2014. https://doi.org/10.3389/fpls.2014.00631

MARSCHNER, H. Mineral nutrition of higher plants. $2^{\text {nd }}$ ed. London: Academic Press, 1995. ISBN: 978-0$12-473542-2$

MCLEAN, E. O. Soil pH and lime requirement. In: Page AL et al., editors. Method of Soil Analysis, Part 2 , $2^{\text {nd }}$ ed. USA: American Society of Agronomy Inc. pp. 199-208, 1982.

http://doi.org/10.2134/agronmonogr9.2.2ed.c12

MEHDI, S. M.; SARFARAZ, M.; SHAH, S. A. A. Response of wheat to applied supplemental potassium in saline-sodic soils. Journal of Biological Science, v. 7, n. 5, p. 823-826. 2007. ISSN 1727-3048

MENGAL, K.; KIRKBY, E. A. Principles of plant nutrition. $4^{\text {th }}$ ed. Switzerland: International Potash Institute; 1987. ISBN 978-94-010-1009-2 
NABIPOUR, M.; MESKARBASHEE, M.; FARZAD, S. Sodium and potassium accumulation in different parts of wheat under salinity levels. Asian Journal of Agricultural Research, v. 1, p. 97-104, 2007.

https://doi.org/10.3923/ajar.2007.97.104

NIAZI, M. H. K.; MEHDI, S. M.; IQBAL, J. Phosphorus requirement of rice and wheat in saline-sodic and sodic soils. Islamabad, Pakistan: Symposium on the role of Phosphorus in crop production, NDFC; July 15-17, pp. 439-449, 1990.

NISTE, M.; VIDICAN, R.; ROTAR, I.; STOIAN, V.; POP, R.; MICLEA, R. Plant Nutrition Affected by Soil Salinity and Response of Rhizobium Regarding the Nutrients Accumulation. Pro Environ, v. 7, p. 71-75, 2014. $\mathrm{http} / /$ journals.usamvcluj.ro/index.php/promediu

NETONDO, G. W.; ONYANGO, J. C.; BECK, E. Crop physiology and metabolism, sorghum, and salinity. 1. Response of growth, water relations, and ion accumulation to $\mathrm{NaCl}$ salinity. Crop Science Society of America, v. 44, p. 797-805, 2004. https://doi.org/10.2135/cropsci2004.7970

RASHID, A. Salinity, and associated nutrient constraints in the Indian subcontinent. Philadelphia, Pennsylvania, USA: $18^{\text {th }}$ World Congress of Soil Science; July 9-15, 2006.

RÖMHELD, V.; KIRKBY, E. Research on potassium in agriculture needs and prospects. Plant and Soil, v. 335, p. 155-180, 2010. http://doi.org/10.1007/s11104-010-0520-1

SINGH, D.; DANG, Y.; DALAL, R.; ROUTLEY, R.; MANN, M. The effect of P and K Nutrition on the tolerance of wheat and chickpea to subsoil salinity. Perth, WA: $13^{\text {th }}$ Australian Agronomy Conference; 10-15, Sep. 2006.

Soil Survey of Pakistan. Land Resources Inventory and Agricultural Land Use Plan of Kohat District. Lahore, Pakistan: National Agricultural Land Use Planning; 2007.

SPOSITO, G. The Chemistry of Soils. New York: Oxford University Press Inc; 1989.pp. 1-277. ISBN: 9780195313697

SUN, Y.; KONG, X.; LI, C.; LIU, Y.; DING, Z. Potassium retention under salt stress is associated with natural variation in salinity tolerance among Arabidopsis accessions. PloS One. v. 10, n. 5, p. e0124032, 2015. https://doi.org/10.1371/journal.pone.0124032

THOMAS, G. W. Soil pH and soil acidity. In: Sparks DL, editor. Methods of Soil Analysis. Part 3. USA: American Society of Agronomy; pp. 475-490, 1996. http://doi.org/10.2136/sssabookser5.3.frontmatter

TZORTZAKIS, N. G. Potassium, and calcium enrichment alleviate salinity-induced stress in hydroponically grown endives. Horticultural Science, Prague, v. 37, p. 155-162, 2010.

WAGDI, E. M.; METWALLY, S. M.; MATAR, M. K.; YOUSEF, N. N. Effect of phosphorus in the alleviation of adverse impacts of salinity on wheat grown on different soils. Communications in Soil Science and Plant Analysis, v. 44, n. 13, p. 1921-1936, 2013. https://doi.org/10.1080/00103624.2013.795227 